\title{
TREATMENT OF SNAP BEAN PLANTS GROWN UNDER SANDY SOIL CONDITIONS WITH SOME NATURAL MATERIALS AND ITS RELATION TO GROWTH, YIELD AND POD QUALITY
}

\author{
Hala A. El-Sayed ${ }^{1}$; M. M. Zaghloul ${ }^{1}$; K. A. M. Nour ${ }^{2}$ and \\ Rasha H. Attia ${ }^{2}$ \\ 1- Hort. Dept., Fac. Agric., Mansoura Univ., Egypt \\ 2- Hort. Res. Inst., Agric. Res. Center- Egypt Self- Pollination Vegetable \\ Res. Dept.,
}

\begin{abstract}
Two field experiments were carried out during the fall seasons of 2012 and 2013 at the Agriculture Research Farm, El-Kassasien Hort. Res. Station, Ismalia Governorate, Egypt, and storage Lab., Hort. Dept., Fac. of Agric., Zagazig University, to study the effect of seed and soil inoculation (arbuscular mycorrhizal fungi, soil yeast) as well as foliar application with some natural materials (pigeon manure tea, compost tea, humic acid and effective microorganisms) on growth, photosynthetic pigments, yield and its components as well as chemical constituents of snap bean pods (Phaseolus vulgaris L.) cv. Paulista. It aimed also to study the effect of the abovementioned treatments on snap bean pods storability during cold storage at $7{ }^{\circ} \mathrm{C}$ and $90-95 \% \mathrm{RH}$ in different periods, i.e., 7, 14,21 and 28 days. Results show that there were significant increases in vegetative growth characters, photosynthetic pigments, yield and it's components as well as some chemical constituents of pods as a_result of snap bean seeds inoculation with AMF plus application with soil yeast around root zone by using hand sprayer as compared to other treatments.

Spraying snap bean plants with pigeon manure tea at $10 \mathrm{~g} / \mathrm{L}$ recorded maximum values of vegetative growth characters, photosynthetic pigments, yield and it's components as well as chemical constituents of pods followed by humic acid at $3 \mathrm{~cm}^{3} / \mathrm{L}$ as compared to the control.

The interaction treatment between dual inoculation with AMF and soil yeast and foliar spray with pigeon manure tea gave the highest values of vegetative growth characters, photosynthetic pigments, yield and it's components as well as chemical constituents of pods followed by the interaction treatment between dual inoculation with AMF and soil yeast and foliar spray with humic acid.

Generally, quality parameters of snap bean pods during cold storage at $7{ }^{\circ} \mathrm{C}$ and $90-95 \mathrm{RH}$ indicate that weight loss was increased, while dry matter, tota carbohydrates and crude protein percentage in snap bean pods were decreased as the storage period prolonged up to 28 days from the beginning of storage period. Green pods obtained from plants treating by dual inoculation with AMF and soil yeast and sprayed with pigeon manure tea or humic acid and stored at $7{ }^{\circ} \mathrm{C}$ and $90-95 \mathrm{RH}$ for 21 days was the best interaction treatment recorded the lowest values of weight loss and the best values of dry matter, total carbohydrates and crude protein percentage.
\end{abstract}

Keywords: AMF, soil yeast, pigeon manure tea, compost tea, humic acid, effective microorganisms, snap bean, growth, yield, chemical constituents, storage period. 


\section{INTRODUCTION}

Snap bean (Phaseolus vulgaris L.) is one of the most important vegetable crops grown in Egypt for both local consumption and exportation. Such importance comes from the fact that legumes are cheap and very rich in protein content, minerals and vitamins which is essential for human nutrition rather than the role of such crops in improving soil fertility (Kerlous, 1997 and Abdel-Hakim et al., 2012).

Uses of mineral fertilizers (NPK) without rationalization may cause environmental pollution as well contaminate the underground water. For these reasons, there was a great attention to use biofertilizers in production of snap bean in order to reduce plant and soil contamination with different elements and decline the usage of mineral fertilizers as well as produce clean crop and also to improve the soil properties. Biofertilizers (microbial inoculation), which contain efficient strains of nitrogen fixing, could be used partially instead of chemical nitrogen fertilizers. Moreover, these bacterial cells increase the availability of nutrients in the form that can be easily absorbed by plants (Subba Rao, 1993).

Arbuscular Mycorrhizal (AM) fungi are found in many soils around the world, and they form association with $80 \%$ of all terrestrial plant roots (Harley and Harley, 1987). AM fungi helps in water regulation of plants by extending their hyphae towards the available moisture zone for continuous water absorption and translocating it to plants. AM association can affect the host plants in terms of stomatal movement and photosynthesis of leaves and has been shown to increase the rate of transpiration, photosynthesis and chlorophyll content (Panwar, 1991). The beneficial effects of AM fungi symbiotic association on the growth of plants are well known (Rajasekaran and Nagarajan, 2004).

Treatment snap bean plants with AM fungi significantly increased vegetative growth, chlorophyll content, chemical composition of pods and yield and its components as compared to the control (El-Shimi, 2004). Massoud et al. (2009) found that inoculation snap bean plants with the mixture of AM- fungi, symbiotic and a symbiotic $\mathrm{N}_{2}$-fixers and Bacillus circulans + rock phosphate + feldspar) was superior in plant height, number of branches, and fresh yield (ton/fed) when compared with the control. Inoculation Vigna unguiculata L. with arbuscular mycorrhizal fungi gave a significant increase in root length, shoot height, dry weight of root and shoot, percentage of mycorrhizal infection, chlorophylls $a, b$ and total chlorophyll (Arumugam et al., 2010). Interaction between Mycorrhiza and Rhizobium showed the highest seed yield and biological yield of snap bean plants (Safapour et al., 2011).

Yeast is considered as a natural source of Bs vitamins and most of the essential elements (Nagodawithana, 1991). Yeasts in root zone may influence plant growth indirectly by encouraging the growth of other plant growth promoting rhizomicroorganisms, combined inoculation of AM fungus and Saccharomyces cerevisiae resulted in highest vegetative growth, chlorophyll content, nitrogen and phosphorus uptake as well as pod yield of cowpea plants (Body et al., 2007). 
Foliar spray with yeast had a simulative effect on vegetative growth, chlorophyll content and yield and its components (Nour and Eisa, 2009 and Abdel-Hakim et al., 2012 on snap bean; Mohamed, 2014 on pea and Marzauk et al., 2014 on broad bean) .

Compost and pigeon manure tea, in modern terminology are a compost and pigeon manure extract, plant extracts, liquid manure and compost teas can by further understood in the context of their influences on the rhizosphere and phyllosphere. Also, manure and compost tea production is a brewing process that extracts microorganisms from compost or manure followed by microbial growth and multiplication including beneficial bacteria, fungi and protozoa (Ingham, 2005). Foliar spray with manure tea had simulative effect on vegetative growth, chlorophyll content and yield and its components, Moyin-Jesu (2003) for goat dung, turkey and duck manure tea fertilizers on locust bean, El-Nakma (2008) for compost tea on pea, Ahmed and Elzaawely (2010) and Kurtar (2013) for pigeon manure on cowpea and cabbage.

Humic acid is a commercial product contains many elements which improve the plant growth. Many investigators reported that spraying snap bean plants with humic acid improved plant growth, productivity and quality (El-Bassiony et al., 2010; Hanafy et al., 2010; Shehata and El-Helaly, 2010) and Shafeek et al. (2013) on broad bean.

Many researchers reported that spraying plants with effective microorganisms (EM) encouraged plant growth, productivity and quality (Javaid and Mahmood, 2010 on soybean and Dawa et al., 2013 on pea).

Thus, this work aimed to study the effect of soil and foliar spray with some natural materials (arbuscular mycorrhizal fungi, soil yeasts, humic acid, compost tea, pigeon manure tea and effective microorganisms) on improving growth, photosynthetic pigments, yield and its components and pods quality as well as increasing storability of green snap bean pods grown under sandy soil conditions.

\section{MATERIALS AND METHODS}

\section{Field experiment:}

The present investigation was carried out during the fall seasons of 2012 and 2013 at the Agriculture Research Farm, El-Kassasien Hort. Res. Station, Ismalia Governorate, Egypt. It aimed to study the effect of soil and seed treatment as well as foliar spray with some natural materials (arbuscular mycorrhizal fungi, soil yeast, pigeon manure tea, compost tea, humic acid and effective microorganisms) on growth, photosynthetic pigments, yield and its components as well as some chemical constituents of snap bean pods (Phaseolus vulgaris L.) cv. Paulista. The physical and chemical analysis of the experimental soil is presented in Table 1 according to Chapman and Pratt (1982). 
Table 1: The physical and chemical properties of the experimental soil (average of two seasons).

\begin{tabular}{|l|c|l|c|}
\hline \multicolumn{2}{|l|}{ Physical properties } & Chemical properties \\
\hline Coarse sand (\%) & 5.9 & Organic matter (\%) & 0.29 \\
\hline Fine sand (\%) & 78.8 & Available K (ppm) & 119.3 \\
\hline Silt (\%) & 8.6 & Available P (ppm) & 4.85 \\
\hline Clay (\%) & 6.7 & Available N (ppm) & 21.7 \\
\hline Field capacity & 6.8 & Calcium carbonate (\%) & 3.97 \\
\hline Wilting point & 2.5 & pH & 7.8 \\
\hline Available water & 4.5 & EC dS.m ${ }^{-1}(1: 5)$ & 0.59 \\
\hline Water holding capacity & 14.5 & S.P\% & 23.5 \\
\hline
\end{tabular}

Seeds of snap bean cv. Paulista were obtained from Hort. Res. Inst., Agric. Res. Center, Egypt, and sown on September $15^{\text {th }}$ and $18^{\text {th }}$ in 2012 and 2013, respectively on one side of drippers lines (two seeds /hill) at $10 \mathrm{~cm}$ apart. At 15 days from sowing, plants were thinned leaving one plant / hill. The experimental unit area was $10.5 \mathrm{~m}^{2}$, it contained 3 dripper lines with $5 \mathrm{~m}$ length each with $70 \mathrm{~cm}$ wide with 150 plant per plot. One dripper line was left between each two experimental units without spraying as a guard row to avoid the overlapping of spraying solution.

This experiment included twenty treatments which were the combination between four seed and soli inoculation treatments and five foliar application. Treatments were arranged in a split plot design with three replicates seed and soil inoculation treatments were assigned at random in the main plots, while sub-plots were devoted to foliar application treatments. The treatments carried out in this study were as follows:

Main plots (seed and soil inoculation):

1-Control (without) 2- Arbuscular mycorrhizal fungi (AMF) at $1 \mathrm{~kg} / \mathrm{fed}$.

3- Soil yeast at $10 \mathrm{~L} / \mathrm{fed}$. 4- AMF + soil yeasts.

Sub-plots (foliar application):

1- Control (tab water) 2- pigeon manure tea at $10 \mathrm{~g} / \mathrm{L} \quad 3$ - Compost tea at $10 \mathrm{~g} / \mathrm{L}$ 4- Humic acid at $3 \mathrm{~cm}^{3} / \mathrm{L} \quad$ 5- Effective microorganisms (EM) at $3 \mathrm{~cm}^{3} / \mathrm{L}$.

Snap bean plants were sprayed three times during the growth period after 20, 30 and 40 days from sowing. Each experimental unit received $2 \mathrm{~L}$ spraying solution using spreading agent (Super Film) in all treatments. The untreated plants (check) were sprayed with $2 \mathrm{~L}$ tap water with spreading agent.

Mature compost and pigeon manure were soaked by tied each dose $(10 \mathrm{~g} / \mathrm{L}$ water) in a cotton tissue and left hanged for 48 hours in a plastic bucket, sized $20 \mathrm{~L}$ until the water turns into brown in color and the extract had no smell, then used for spraying.

The composition of compost and pigeon manure tea is listed in Table 2. 
Table 2: Some chemical characteristics of the used organic tea .

\begin{tabular}{|l|c|c|}
\hline parameters & Pigeon tea & Compost tea \\
\hline $\mathrm{pH}(1: 5)$ & 6.15 & 6.72 \\
\hline EC dS.m & 5.07 & 5.65 \\
\hline Total N ppm & 89.7 & 58.9 \\
\hline Total P ppm & 16.9 & 13.4 \\
\hline Total K ppm & 465 & 398 \\
\hline Total Fe ppm & 33.8 & 26.3 \\
\hline Total Mg ppm & 11.3 & 8.6 \\
\hline Total Zn ppm & 9.7 & 6.9 \\
\hline
\end{tabular}

Arbuscular mycorrhizal fungi (AMF) inoculum was prepared as described by Massoud et al. (2009). Mixed surface sterilized spores of AM genera via, Glomus, Gigaspora and Acaulospora were prepared after propagation and mixed with sterilized vermiculite $20 \%$ as a carrier (500 spore / $\mathrm{g}$ vermiculite). Then adhesion using sticker such as Arabic gum and uniformly coated on the seeds and air dried for 1 hour before planting.

The yeast strain (Saccharomyces cerevisiae) was grown on glucose peptone yeast (GPY) liquid medium contains $2 \%$ glucose, $0.5 \%$ peptone $0.3 \%$ yeast extract (Difco, 1985). This medium was autoclaved at $121{ }^{\circ} \mathrm{C}$ for $20 \mathrm{~min}$ then the strain inoculated with loop full and incubated at $30^{\circ} \mathrm{C}$ for $48 \mathrm{~h}$ on rotary shaker at $150 \mathrm{rpm}$. The inoculum of yeast strain $\left(1 \times 10^{7} \mathrm{CFU} / \mathrm{ml}\right)$ were added two times around root zone by using hand sprayer at a rate of 10 L/fed in twice after 15 and 30 days from sowing. Arbuscular mycorrhizal fungi and yeast strain were obtained from the microbiology department, Soils, Water and Environment Res. Inst., Agric. Res. Center, Giza, Egypt.

All plots received equal amounts of compost at a rate of 20 $\mathrm{m}^{3} / \mathrm{feddan}$ during soil preparation, and $50 \%$ of recommended nitrogen fertilizer rate $(120 \mathrm{~kg} / \mathrm{fed}$.) ammonium nitrate $(33.5 \% \mathrm{~N})$ was added in three equal doses during soil preparation, at 20 and 40 days after sowing, the other recommended agricultural practices for commercial snap bean production; i.e., irrigation, phosphorus and potassium fertilization and weed control were followed according to Agriculture Ministry recommendation for snap bean.

Data recorded: The obtained data in this study were recorded as follows:

A. vegetative growth characters: Six plants from each plot were randomly taken at 50 days after sowing to evaluate Plant height, number of leaves and branches/plant and dray weight of foliage.

B. Photosynthetic pigments: Disk samples from the fourth upper leaf on the main stem were taken at 50 days after sowing to determine chlorophyll $a, b$ and total chlorophyll $(\mathrm{a}+\mathrm{b})$ as well as carotenoids according to Wettestein (1957).

\section{Yield and its components:}

Green pods of each experimental unit were continuously harvested at suitable maturity stage counted and weighed in each harvest till the end of the experiment and the following data were recorded: Average number of pods/plant, average pod weight, green pods yield /plot and total green pods yield /fed. At the second harvest, ten pods from each experimental unit were randomly taken to measure average pod length . 


\section{Pod chemical constituents:}

Sample of green pods from each experimental unit was oven dried at $70{ }^{\circ} \mathrm{C}$. It finely ground separately and digested with sulfuric acid and percholoric acid (3:1). Nitrogen\%, phosophorus \% and potassium \% were determined according to the method described by Bremner and Mulvaney (1982), Olsen and Sommers (1982) and Jackson (1970), respectively. crude protein was calculated by multiplying the total nitrogen by 6.25 . Total carbohydrates were determined colorimetrically using the method described by Dubois et al. (1956).

\section{Storage experiment:}

This experiment was conducted to study the effect field experiment on keeping quality of snap bean green pods during cold storage, mature green pods from the field experiment, were harvested at suitable maturity stage for marketing on $15^{\text {th }}$ November and transported soon to the handling Lab., Hort. Dept., Fac. of Agric., Zagazig University, Egypt, and kept overnight at $7{ }^{\circ} \mathrm{C}$ and $90-95 \%$ relative humidity $(\mathrm{RH})$. Marketable green snap bean pods $(250 \mathrm{~g})$ packed in micro perforated polypropylene bags $12 \times 15 \mathrm{~cm}$ (with $30 \mu$ thickness) sealed hermetically. Twelve polypropylene bags were prepared for each treatment, placed in carton box $(30 \times 20 \times 10 \mathrm{~cm})$, then stored at $7{ }^{\circ} \mathrm{C}$ and $90-95 \% \mathrm{RH}$ for 28 days. Three polypropylene bags were randomly taken from each treatment every 7 days for determining the postharvest measurements. The experimental design was completely randomized with three replicates.

Pod physical and chemical properties were recorded as follow:

A. Weight loss (\%): It was calculated according to the following equation:

Initial weight of pods - Weight of pods at sampling dates

Weight loss (\%) $=$

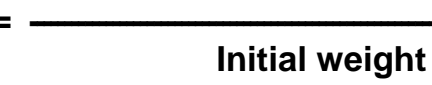

B. Dry matter (\%): It was determined after drying at $70{ }^{\circ} \mathrm{C}$ till constant weight.

C. Total carbohydrates and crude protein (\%) were determined as aforementioned in the first experiment.

Statistical analysis: data of the field experiment and cold storage experiment were statistically analyzed using MSTAT statistical software and the treatments means were compared using LSD at 0.5 level of probability according to Snedecor and Cochran (1980).

\section{RESULTS AND DISCUSSION}

Growth characters and photosynthetic pigments :

Effect of seed and soil inoculation:

It is obvious from the data presented in Table 3 that treating snap bean seeds with AMF or /and soil yeast significantly increased vegetative growth characters expressed as plant height, number of leaves and branches per plant as well as total dry weight in addition to photosynthetic pigments, the most favorable treatment for enhancing growth characters and photosynthetic pigments was the dual inoculation with AMF and soil yeast 
than the individual treatment with AMF or soil yeast. on the other hand the lowest values in this respect were recorded generally in case of the control.

The beneficial effect of yeast application on growth parameters of snap bean plants may be due to that yeast (Saccharomyces Cerevisiae) as a natural source for cytokinins had stimulatory effects on cell division, cell enlargement, protein and nucleic acid synthesis as well as chlorophyll formation (Spencer et al., 1983). Also yeast was found to contain carbohydrate, amino acids and lipids as well as several vitamins and most nutritional elements, i.e., $\mathrm{Na}, \mathrm{Ca}, \mathrm{Fe}, \mathrm{Mg}, \mathrm{K}, \mathrm{P}, \mathrm{S}, \mathrm{Zn}$ and $\mathrm{Si}$ (Nagodawithana, 1991).

Such stimulative effect of AMF on the chlorophyll content may be due to the increase in stomatal conductance, photosynthesis, transpiration and enhanced plant growth (Rajasekaran et al., 2006) or due to the presence of large and more numerous bundle sheath chloroplasts in the inoculated leaves (Krishna and Bagyaraj, 1984). Obtained results are agreeable with those reported by Nour and Eisa (2009), Abdel-Hakim et al. (2012) on snap bean, Mohamed (2014) on pea and Marzauk et al. (2014) on broad bean for yeast. Similar findings with AMF were obtained by El-Shimi (2004), Massoud et al., (2009) on snap bean and Arumugam et al. (2010) on cow pea. Effect of foliar application:

Presented data in Table 3 indicate that spraying snap bean plants with all tested treatments, i.e., pigeon manure tea, compost tea, humic acid and EM had significant increase on vegetative growth characters and photosynthetic pigments as compared to untreated plants, the superior treatments in this respect were pigeon manure tea followed by humic acid. These results are true in both growing seasons. The increase in vegetative growth characters and photosynthetic pigments of snap bean plants by using pigeon manure tea solution could be due to its high $\mathrm{N}, \mathrm{P}, \mathrm{K}, \mathrm{Fe}, \mathrm{Mg}$ and $\mathrm{Zn}$ contents (Table 2). Whereas the beneficial effects of humic acid on plant growth could be referred to its acting as source of plant growth hormones (Nardi et al., 1999).

Similar findings with manure tea foliar application were obtained by Moyin-Jesu (2003) for goat dung, turkey and duck manure tea fertilizers on locust bean, El-Nakma (2008) for compost tea on pea, Ahmed and Elzaawely (2010) and Kurtar (2013) for pigeon manure on cowpea and cabbage. In addition, the obtained results with humic acid foliar nutrition agree with those of El-Bassiony et al. (2010), Hanafy et al. (2010), Shehata and El-Helaly (2010) on snap bean and Shafeek et al. (2013) on broad bean. Effect of the interaction:

It is evident from the results in Table 4 that such interaction treatments generally had a promotive effect on vegetative growth and photosynthetic pigments of snap bean plants, the interaction between dual inoculation with AMF and soil yeast beside foliar application with pigeon manure tea resulted in the maximum values of abovementioned characters followed by the interaction between dual inoculation with AMF and soil yeast in addition to foliar application with humic acid at $3 \mathrm{~cm}^{3} / \mathrm{L}$ as compared to other treatments in both growing seasons. 
Hala A. El-Sayed et al.

3- 
J. Plant Production, Mansoura Univ., Vol. 6 (3), March, 2015

4- 
Yield and yield components:

Effect of seed and soil inoculation:

The data listed in Table 5 clearly show that treating snap bean seeds with AMF or /and soil yeast significantly increased yield and yield components expressed as pod length, number of pods per plant, average pod weight, yield per plot and total yield per feddan as well as yield increase over the control (\%). In this respect, the superior treatment for enhancing yield and its components was the dual inoculation with AMF and soil yeast than the individual treatment with AMF or soil yeast. On the other hand the lowest values in this respect were recorded generally in case of the control treatment. The enhancing effect of yeast on snap bean yield and its components may be due to that yeast via its cytokinins content and the high content of vit. B and nutrient elements as well as organic compounds (Nagodawithana, 1991), which play a role in distribution and translocation of metabolites from leaves towards the reproductive organs which lead to the improvement of snap bean yield.

The enhancing effect of AMF on snap bean yield and its components may be due to that AMF can solubilize surrounding weatherable minerals through excretion of organic acids such as a-ketoglutaric acid. This organic compound could exert a selective influence on soil microbial communities though a multiplication of a-ketoglutarate catabolizing microorganisms (Duponnois et. al., 2005).

Obtained results are agreeable with those reported by Nour and Eisa (2009), Abdel-Hakim et al. (2012) on snap bean, Mohamed (2014) on pea and Marzauk et al. (2014) on broad bean for yeast. Similar findings with AMF were obtained by El-Shimi (2004), Massoud et al., (2009) and Safapour et al., (2011) on snap bean.

Effect of foliar application:

Illustrated data in Table 5 indicate that spraying snap bean plants with all tested treatments, i.e., pigeon manure tea, compost tea, humic acid and EM had significant increase on yield and its components as compared to untreated plants. In this connection, the superior treatment was pigeon manure tea followed by humic acid. These results are true in both growing seasons. The increase in yield of snap bean plants by using pigeon manure tea solution may be attributed to the enhancement effect of the abovementioned treatment on increasing plant growth parameters and dry matter accumulation as well as photosynthetic pigments (Table 3 ) this in turn increased yield and its components. The increment in yield as a result of using HA may be due to that HA is extremely important component because it constitute a stable fraction of carbon, thus regulating the carbon cycle and release of nutrients, including nitrogen, phosphorus, and sulfur, which decreasing the need for inorganic fertilizer for plant growth. Humic acid stimulate plant growth by the assimilation of major and minor elements, enzyme activation and/or inhibition, changes in membrane permeability, protein synthesis and finally the activation of biomass production (Ulukan, 2008). 
J. Plant Production, Mansoura Univ., Vol. 6 (3), March, 2015

5- 
Similar findings with manure tea foliar application were obtained by Moyin-Jesu (2003) for goat dung, turkey and duck manure tea fertilizers on locust bean, El-Nakma (2008) for compost tea on pea, Ahmed and Elzaawely (2010) and Kurtar (2013) for pigeon manure on cowpea and cabbage. In addition, the obtained results with humic acid foliar nutrition agree with those of El-Bassiony et al. (2010), Hanafy et al. (2010), Shehata and El-Helaly (2010) on snap bean and Shafeek et al. (2013) on broad bean. Effect of the interaction:

Results in Table 6 illustrate that such interaction treatments generally had a promotive effect on yield and its components of snap bean plants. The interaction between dual inoculation with AMF plus soil yeast combined with foliar application of pigeon manure tea resulted in the maximum values of abovementioned characters followed by the interaction between individual inoculation with soil yeast and foliar application with pigeon manure tea and individual inoculation of seed with AMF plus foliar application with pigeon manure tea without significant differences among them as compared to other treatments in both growing seasons.

\section{Chemical constituents of pods:}

\section{Effect of seed and soil inoculation:}

It is obvious from the data presented in Table 7 that treating snap bean plants with AMF or /and soil yeast significantly increased chemical constituents of snap bean pods expressed as dry matter, N, P, K, and crude protein as well as total carbohydrates (\%). In this regard, the most favorable treatment for enhancing chemical constituents of pods was the dual inoculation with AMF and soil yeast than the individual treatment with AMF or soil yeast. On the other hand, the lowest values in this respect were recorded generally in case of the control treatment.

The increases of chemical constituents by treating with yeast might be attributed to that macro and micronutrients increases in the capacity of plant to absorb nutrients by the increase of root surface per unit of soil volume, as well as, the high capacity of the plants supplied with macro and micronutrients in building up plant metabolites, which in turn contributes much to the increase of nutrients uptake (Mandour et al., 1986).

These results are in agreement with those reported by Nour and Eisa (2009), Abdel-Hakim et al. (2012) on snap bean, Mohamed (2014) on pea and Marzauk et al. (2014) on broad bean for yeast. Similar findings with AMF were obtained by El-Shimi (2004) on snap bean.

\section{Effect of foliar application:}

Statistical analysis of data in Table 7 clear that spraying snap bean plants with all tested treatments, i.e., pigeon manure tea, compost tea, humic acid and EM had significant increase on chemical constituents of snap bean pods as compared to untreated plants. In addition, the superior treatment in this respect was pigeon manure tea followed by humic acid. Obtained results are true in both growing seasons. The stimulative effect of humic acid on macronutrients concentrations might be explained by David et al. (1994) who indicated that humic acid enhanced cell permeability, which in turn made more rapid entry of minerals into root cells and so resulted in higher uptake of plant nutrients. 
J. Plant Production, Mansoura Univ., Vol. 6 (3), March, 2015

6- 
Hala A. El-Sayed et al.

7- 
The obtained results with humic acid foliar nutrition agree with those of El-Bassiony et al. (2010), Hanafy et al. (2010), Shehata and El-Helaly (2010) on snap bean and Shafeek et al. (2013) on broad bean.

\section{Effect of the interaction:}

Results in Table 8 illustrate that such interaction treatments generally had a promotive effect on chemical constituents of snap bean pods, the interaction between dual inoculation with AMF and soil yeast plus foliar application with pigeon manure tea resulted in the maximum values of abovementioned chemical constituents followed by the interaction between individual inoculation with AMF and foliar application with pigeon manure tea without significant differences between them as compared to other treatments in both growing seasons.

\section{Cold Storage Experiment: \\ Weight loss and dry matter percentage: \\ Effect of seed and soil inoculation:}

illustrated data in Table 9 indicate that seed inoculation with AMF and soil inoculation with soil yeast had significant effect on weight loss and dry matter (\%) as compared to control treatment during cold storage. The superior treatment in this respect was the dual inoculation with AMF and soil yeast which significantly decreased weight loss (\%) and increased dry matter $(\%)$ in the cold stored snap bean pods.

As for cold storage period, it is clear from the same data that there was a considerable increase in weight loss and dry matter (\%) of snap bean pods as the cold storage period prolonged, where the maximum values were occurred at the end of cold storage period (28 days). It reached 19.62 and $19.30 \%$ for weight loss and 16.20 and $17.06 \%$ for dry matter in the $1^{\text {st }}$ and $2^{\text {nd }}$ seasons respectively. The increment in dry matter percentage may be due to the higher rate of moisture loss through transpiration than that of dry matter through respiration (Abdalla, 2008). While, this continuous loss in weight during cold storage resulted from the loss of water by transpiration and dry matter by respiration (Atta-Aly, 1998).

\section{Effect of foliar application:}

It is obvious from the data presented in Table 9 that preharvest spraying snap bean plants with all tested substances had significant effect on weight loss and dry matter (\%) as compared to the control treatment during cold storage. The superior treatments in this respect were pigeon manure tea followed by EM at $3 \mathrm{~cm}^{3} / \mathrm{L}$ and humic acid which significantly decreased weight loss (\%) and increased dry matter (\%) in the cold stored snap bean pods, where pigeon manure tea recorded 20.77 and $20.02 \%$ for weight loss and 17.02 and $17.84 \%$ for dry matter, nevertheless EM recorded 21.58 and $20.86 \%$ for weight loss, and gave 15.26 and $15.93 \%$ for dry matter in $1^{\text {st }}$ and $2^{\text {nd }}$ seasons, respectively.

As for cold storage period, it is clear from the same data that there was a considerable increase in weight loss and dry matter (\%) of snap bean pods as the cold storage period prolonged, where the maximum values were occurred at the end of cold storage period (28 days). 
Hala A. El-Sayed et al.

8- 
J. Plant Production, Mansoura Univ., Vol. 6 (3), March, 2015

9- 
Hala A. El-Sayed et al.

10- 


\section{Effect of the interaction:}

With regard to the interaction among soil, foliar application and cold storage period the results in Table 10 show significant effect in both seasons, the minimum values of weight loss (\%) and maximum values of dry matter $(\%)$ at the end of cold storage period (28 days) were noted in pods obtained from snap bean plants treated by dual inoculation with AMF and soil yeast beside spraying with pigeon manure tea. These results are true in both seasons of study.

\section{Total carbohydrates and crude protein percentage:}

\section{Effect of seed and soil ionculation:}

It is obvious from the data in Table 11 that preharvest treating snap bean plants with all tested substances had significant effect on increasing total carbohydrates and crude protein (\%) as compared to control treatment during cold storage. The superior treatments in this respect were the dual inoculation with $\mathrm{AMF}$ and soil yeast followed by individual treatment with AMF which significantly increased total carbohydrates and crude protein (\%) in the cold stored snap bean pods.

As for cold storage period, it is clear from the same data that there was a considerable decrease in total carbohydrates and crude protein (\%) of snap bean pods as the cold storage period prolonged, where the minimum values were occurred at the end of cold storage period (28 days). It reached 22.73 and 22.28 $\%$ for total carbohydrates and 17.55 and $15.31 \%$ for crude protein in the $1^{\text {st }}$ and $2^{\text {nd }}$ seasons respectively. The reduction in total carbohydrates content during cold storage may be due to the higher rate of sugar loss through respiration than the water loss through transpiration (Wills et al., 1981).

\section{Effect of foliar application:}

Data illustrated in Table 11 indicate that preharvest spraying snap bean plants with all tested substances had significant effect on increasing total carbohydrates and crude protein (\%) as compared to the control treatment during cold storage. The superior treatments in this respect were pigeon manure tea and humic acid at $3 \mathrm{~cm}^{3} / \mathrm{L}$ which significantly increased total carbohydrates and crude protein (\%) in the cold stored snap bean pods, where pigeon manure tea recorded 26.60 and $26.34 \%$ for total carbohydrates and 20.31 and $19.27 \%$ for crude protein, nevertheless humic acid gave 26.17 and $25.31 \%$ for total carbohydrates and 19.17 and $18.33 \%$ for crude protein in $1^{\text {st }}$ and $2^{\text {nd }}$ seasons, respectively.

As for cold storage period, it is clear from the same data that there was a considerable decrease in total carbohydrates and crude protein (\%) of snap bean pods as the cold storage period prolonged, where the minimum values were occurred at the end of cold storage period (28 days).

\section{Effect of the interaction:}

With regard to the interaction among seed and soil inoculation, foliar application and cold storage period the results in Table 12 show significant effect in both seasons, the maximum total carbohydrates and crude protein (\%) at the end of cold storage period (28 days) were noted in pods obtained from snap bean plants treated by dual inoculation with AMF and soil yeast beside spraying with pigeon manure tea followed by individual treatment with AMF. These results are true in both seasons of study. 
Hala A. El-Sayed et al.

11- 
J. Plant Production, Mansoura Univ., Vol. 6 (3), March, 2015

12 
Hala A. El-Sayed et al.

13- 


\section{Correlation study:}

Presented data in Table 13 show the simple correlation coefficient between total yield (ton/feddan) and number of pods per plant. The results indicated that total yield (ton / feddan) showed positive and highly significant correlation with number of pods per plant, average pod weight and green pod yield ( $\mathrm{kg} / \mathrm{plot})$ in both seasons. These results are in a good line with those reported by Ismail and Mohamed (2014). Number of pods per plant did not reflected any significant correlation with average pod weight, but it showed highly and positively significant correlation with green pod yield per plot $\left(0.546^{* *}\right)$ and $\left(0.536^{*}\right)$ in the $1^{\text {st }}$ and $2^{\text {nd }}$ seasons, respectively. Moreover, average pod weight $(\mathrm{g})$ recorded positive and highly significant association with green pod yield (kg/plot) and recorded $\left(0.929^{* *}\right)$ and $\left(0.836^{*}\right)$ in the $1^{\text {st }}$ and $2^{\text {nd }}$ seasons, respectively.

\section{CONCLUSION}

From the previous results of this investigation, it could be concluded that treating snap bean seeds cv. Paulista grown in fall season under sandy soil conditions by dual inoculation with AMF and soil yeast and spraying plants with pigeon manure tea at $10 \mathrm{~g} / \mathrm{L}$ and humic acid at $3 \mathrm{~cm}^{3} / \mathrm{L}$ were the best treatments for maximizing growth, photosynthetic pigments, yield, pod quality and maintained snap bean pods with high quality during cold storage (at $7^{\circ} \mathrm{C}$ and $90-95 \% \mathrm{RH}$ ) for 21 days.

\section{REFERENCES}

Abdalla, M. A. A. (2008). Studies on growth, production and storage of pigeon pea (Cajanus cajan). M.Sc. thesis, Fac. of Agric., Ain Shams Univ., Cairo 70p.

Abdel-Hakim, W. M.; Y. M. M. Moustafa and R. H. M. Gheeth (2012). Foliar application of some chemical treatments and planting date affecting snap bean (Phaseolus vulgaris L.) plants grown in Egypt. J. Hort. Sci. Ornamen. Plants 4 (3): 307-317.

Ahmed, M. A. and A. A. Elzaawely (2010).Growth and yield of cowpea plants in response to organic fertilization. Aust. J. Basic and Appli. Sci., 4 (8): 3244-3249.

Arumugam, R.; S. Rajasekaran and S. M. Nagarajan (2010). Response of Arbuscular mycorrhizal fungi and Rhizobium inoculation on growth and chlorophyll content of Vigna unguiculata (L) Walp Var. Pusa 151. J. Appl. Sci. Environ. Manage. 14 (4): 113 - 115

Atta-Aly, M. A. (1998). Effect of hydro-cooling and polyethylene package lining on maintaining green onion quality for export. Annals Agric. Nal Sci. 43(1): 231-249.

Body, V. U.; A. N. Balakrishna and D. J. Bagyaraj (2007). Effect of combined inoculation of an AM fungus with soil yeasts on growth and nutrition of cowpea in sterilized soil. World J. Agric. Sci., 3 (4): 423-429. 
Bremner, J. M. and C. M. Mulvaney (1982). Total nitrogen. In [Page, A.L., R.H. Miller, and D.R. Keeney] (Eds). Methods of Soil Analysis, Part 2 Amer. Soc. Agron. Madison. WI-W.S.A. p. 595-624.

Chapman, H. D. and P. F. Pratt (1982). Method and of analysis of soil, plant and water. 2nd Ed. California: California University Agricultural Division, pp: 170.

David, P. P.; P. V. Nelson and D. C. Sanders (1994). A humic acid improves growth of tomato seedlings in solution culture. J. Plant Nutr., 17:173184.

Dawa, K. K.; A. H. Amer and M. M. Helmy (2013). Effect of magnetite, humic acid and biofertlizer as well as N, P and K levels application on growth and yield of pea (Pisum sativum L.). J. plant production, Mansoura Univ., 4 (4): 641-654.

Difco, M. (1985). Dehydrated culture media and reagents for microbiology. Laboratories Incorporated Detroit. Michigan, 48232 USA. Pp. 621.

Dubois, M.; R. A. Gilles; J. Hamillon, R. Rebers and I. Smith (1956). Colorimetric method for determination of sugars and related substances. Anal. Chem. 28: 350 - 356.

Duponnois, R.; C. Aline, H. Victor and T. Jean (2005). The mycorrhizal fungs Glomus intraradices and rock phosphate amendment influence plant growth and microbial activity in the rhizosphere of Acocia holosericea. J. Soil Biol. and Biochem., 37: 1460-1468.

El-Bassiony, A. M.; Z. F. Fawzy, M. M. H. Abd El-Baky and Asmaa, R. Mahmoud (2010). Response of snap bean plants to mineral fertilizers and humic acid application. Res. J. Agric. and Biol. Sci., 6 (2): 169-175

El-Nakma, K. A. A. (2008). Impact of including rice straw in preparing compost tea for organic farming. M. Sc. Thesis. Fac. Agric. Mansoura Univ. Egypt 138pp.

El-Shimi, N. M. M. (2004). Physiological studies on growth and productivity of common bean .Ph.D. Thesis. Fac. Argic. Moshtohore, Zagazig Univ. Benha Branch 111PP.

Hanafy A. A. H.; M. R. Nesiem, A. M. Hewedy and H. El-S. Sallam (2010). Effect of some simulative compounds on growth, yield and chemical composition of snap bean plants grown under calcareous soil conditions. J. American Sci., 6 (10): 552-569.

Harley, J. L. and E. L. Harley (1987). A check-list of mycorrhizal in the British flora. New Phytol, 105: 1-102.

Ingham, E., (2005). The compost tea brewing manual as printings. Soil food web incorporated, ovegan, 3:31-32.

Ismail, H. E. M. and O. O. Mohamed (2014). Impact of foliar spray with potassium on the productivity, quality and storability of some sweet pepper hybrids grown in plastic houses. J. Product. \& Dev. 19(2):155 180.

Jackson, M. L. (1970). Soil chemical analysis. Prentice Hall, Englewood Cliffs, N.J.

Javaid, A. and N. Mahmood (2010). Growth, nodulation and yield response of soybean to biofertilizers and organic manures. P. J. Bot., 42 (2): 863871. 
Kerlous, A. N. K. (1997). Effect of sowing dates and water stress on productivity of bean (Phaseolus vulgaris L.) plants. M. Sc. Thesis, Fac. Agric, Ain Shams Univ., Cairo, Egypt.

Krishna, K.R. and D.J. Bagyaraj (1984). Growth and nutrient uptake of peanut inoculated with mycorrhizal fungus Glomus fasciculatum compared with uninoculated ones. Plant and Soil, 17: 405-408.

Kurtar, E. S. (2013). Organic transplant production of some winter vegetable crops in float. Yuzuncu Yil Univ. J. Agric. Sci., 23 (2):83-89.

Mandour, M.S.; S. El-Sherbiny; N.B. Botros and S.H. El-Nagar (1986). Effect of nitrogen application upon growth, oil and nutrient content of citronella grass. Bull. Egypt, Soc. Physiol. Sci. 145(3): 6.

Marzauk, N. M.; M. R. Shafeek; Y. I. Helmy, A. A. Ahmed and M. A. F. Shalaby (2014). Effect of vitamin $E$ and yeast extract foliar application on growth, pod yield and both green pod and seed yield of broad bean (Vicia faba L.). Middle East J. Appli. Sci., 4 (1): 61-67.

Massoud, O. N.; E. M. Morsy, and N. H. El-Batanony, (2009). Field Response of Snap Bean (Phaseolus vulgaris L.) To $\mathrm{N}_{2}$-fixers Bacillus Circulans and Arbuscular Mycorrhizal Fungi Inoculation Through Accelerating Rock Phosphate and Feldspar Weathering. Australian J. Basic and Appl. Sci., 3 (2): 844-852.

Mohamed, Omaima O. (2014). Impact of preharvest foliar spray with some safely substances on yield and storability of fresh cut green pea seeds (Pisum sativum L.) during cold storage. Zagazig J. Agric. Res., 41 (6):1197- 1215.

Moyin-Jesu, E. 1.(2003). Evaluation of plant and animal tea solution fertilizers on the soil fertility and growth of locust bean (Parkia clappertonia) seedlings in the nursery. Pertanika J. Trap. Agric. Sci. 26 (1): 41 - 47

Nagodawithana, W. T. (1991). Yeast technology. Universal Foods Corporation Milwaukee, Wisconsin.Published by Van Nostrand Reinhold New York. P.273.

Nardi, M. R.; P. Diego; R. Fabiano and A. Muscolo (1999). Biological activity of humic substances extracted from soils under different vegetation cover commun. Soil Sci. Plant Anal., 30 (5\&6):621-634.

Nour, K. A. M. and G. S. A. Eisa (2009). Influence of some biofertilizers and foliar application with amino green and yeast on some physiological and anatomical characters of snap bean under sandy soil conditions. Zagazig J. Agric. Res. 36 (5) : 987-1018.

Olsen, S. R. and L. E. Sommers. (1982). Phosphorus In [Page, A.L., R.H. Miller, and D.R. Keeney (Eds.). Methos of Soil Anaylsis, Part 2- Amer. Soc. Agron. Madison. WI- USA pp. 403-430].

Panwar, J. D. S. (1991). Effect of VAM and Azospirillum brasilense on photosynthesis, nitrogen metabolism and grain yield in wheat. Indian $\mathrm{J}$. Plant Physiol., 34: 357-361.

Rajasekaran, S. and S. M. Nagarajan (2004). Occurance and histochemical studies on VAM fungi and some medicinal plants. Asian J. Microbiol. Biotech. Env. Sci., 6 (4): 553-556. 
Hala A. El-Sayed et al.

Rajasekaran, S.,; S.M. Nagarajan; K. Arumugam; R. Sravanamuthu and S. Balamurugan (2006). Effect of dual inoculation (AM fungi and Rhizobium) on chlorophyll content of Arachis hypogaea L. CV. TMV-2. Plant Archives, 6 (2): 671-672.

Safapour, M.; M. Ardakani; S. Khaghani; F. Rejali; K. Zargari; M. Changizi and M. Teimuri (2011). Response of Yield and Yield Components of Three Red Bean (Phaseolus vulgaris L.) Genotypes to Co-Inoculation with Glomus intraradices and Rhizobium phaseoli. American-Eurasian J. Agric. \& Environ. Sci., 11 (3): 398-405.

Shafeek, M. R.; Y. I. Helmy; N. M. Omer and F. A. Rizk (2013). Effect of foliar fertilizer with nutritional compound and humic acid on growth and yield of broad bean plants under sandy soil conditions. J. Appl. Sci. Res., 9 (6) : 3674-3680.

Shehata, S. A. and M. A. El-Helaly (2010). Effect of compost, humic acid and amino acids on yield of snap beans. J. Horti. Sci. \& Ornamen. Plants 4 (3) :107-110.

Snedecor, G. W. and W. G. Cochran (1980). Statistical Methods. $7^{\text {th }}$ Ed. The lowa State Univ. , Press, Amer., lowa, USA .

Spencer, T. F. T.; S. M. Dorothy and A. R. W. Smith. (1983). Yeast genetics, Fundamental and Applied Aspects. pp.16-18 ISBNO. 387-90973-9. Springer- Verlag New York, USA.

Subba Rao, N. S. (1993). Biofertilizers in agriculture. $3^{\text {rd }}$ (ed.), Oxford, IBH publishing Co. Ltd., New Delhi, Bombay, Calcutta, 219 pp.

Ulukan, H., (2008). Effect of soil applied humic acid at different sowing times on some yield components in wheat (Triticum spp.) hybrids Int. J. Bot., 4 (2): 164-175.

Wettestein, D. (1975). Chlorophyll-lethale und der submikroskopische formwechsel der plastiden. Exptl.Cell. Res. 12:427-433.

Wills, R.B.H., T.H. Lee, D. Gerham, W.B. McGlesson and E.G. Hall (1981). Postharvest: An introduction to physiology and handling of fruits and vegetables. Inc Westport, connectiut. 


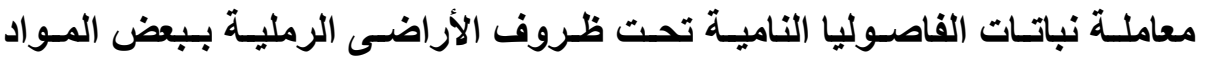

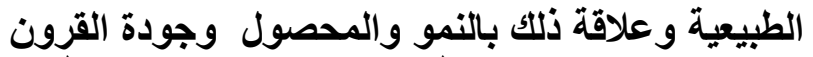

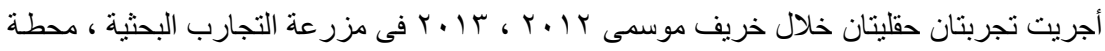

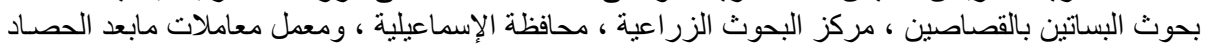

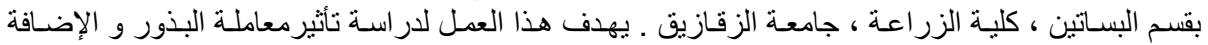

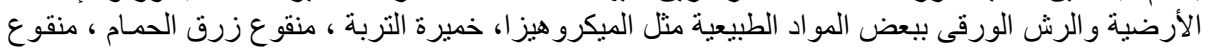

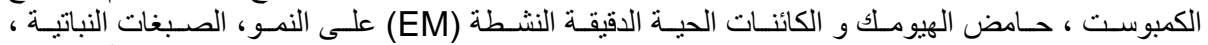

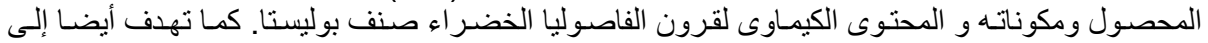

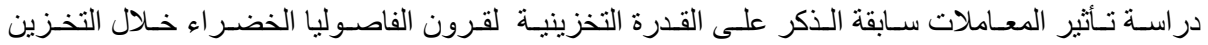

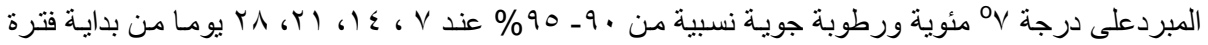

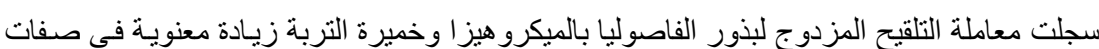
التخزين.

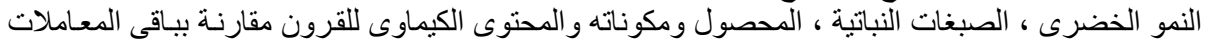

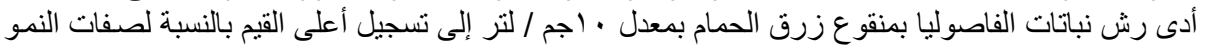

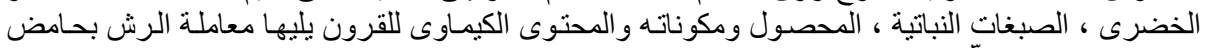
الهيومك بمعدل آسمَّ / لتر مقارنة بالنباتات الغير معاملة.

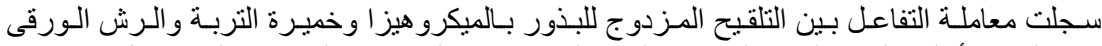

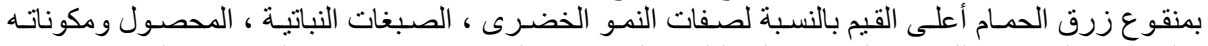

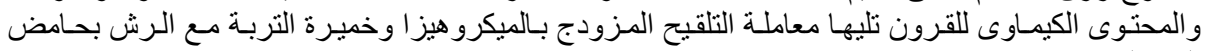

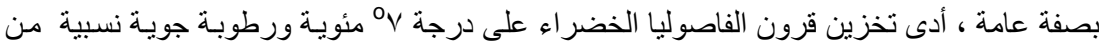
الهيو مك.

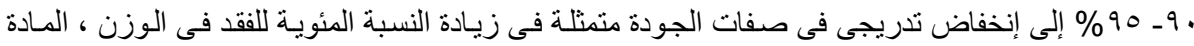

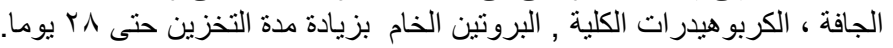

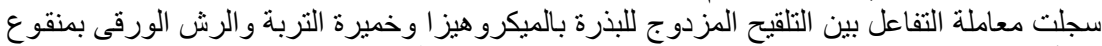

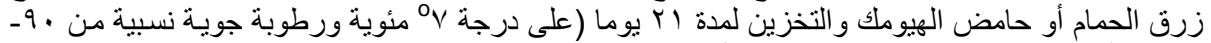
90\%) أقل القيم بالنسبة للفقد فى الوزن ، و أفضل القيم للمادة الجافة ، الكربو هيدرات الكلية , البروتين الخام

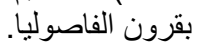


J. Plant Production, Mansoura Univ., Vol. 6 (3): 395 - 421, 2015 